of colour in Western Australia, whether full-blooded or of mixed origin, shall no longer be known as "aborigines", "half-castes", or "near whites", but shall be termed "natives". While this proposal no doubt removes what has been felt in certain circumstances to be a stigma, it perpetuates and gives official approval to a troublesome ambiguity. The Bill was introduced on behalf of the Western Australian Government by the Chief Secretary, Mr. W. H. Kitson (The Times, Sept. 24). As it stands, the proposals deal with certain matters affecting the natives to which attention was directed recently in the drastic report of a commission of inquiry criticizing native conditions and the organization and functioning of the Western Australian Government's provision for the protection of the aborigines (see NaTURE, 135, 798). A better system of control of the natives is to be introduced; and a serious attempt is to be made to grapple with the grave problem of the conditions affecting native mothers and their children; while the employment of young females will be regulated to prevent exploitation by their employers. Other matters which come under view or revision are the terms of native tenure of property and land, the prohibition of the sale of intoxicants to natives, and the delicate question of the curtailment of tribal custom and practices which "are calculated to cause bodily injury or to militate against the Department's work of amelioration". Finally, and in view of past history, perhaps most important of all, native courts are to be established for the trial of offences committed by one native against another. From the brief summary which so far has been transmitted by cable, it would appear that the Government is making a determined effort to remedy the graver defects of its system to which attention has been directed, and that in certain respects the practice of the State will be brought into line with that of the Federal Government in its relations with the aborigines of the Northern Territory.

\section{Foundation Rites at Maiden Castle, Dorchester}

Two important discoveries mark the approach of the closing week of excavation at Maiden Castle, Dorchester, where Dr. R. E. Mortimer Wheeler is at work on behalf of the Society of Antiquaries and the Dorset Natural History and Archæological Society. The adult burial (see Nature, Sept. 5, p. 395) is now found to date from the Iron Age c. 300 B.c. and to be situated at the base of the rampart of the earlier enclosure at the point of contact with the rampart of the larger and later Maiden Castle. The character of the filling of the grave indicates that it is contemporary with the construction of the latter, and its position, as well as the fact that it is the only adult burial so far discovered within the enclosure, fully justify the view taken by Dr. Wheeler that it may possibly have been a ceremonial burial connected with foundation rites, such as are known to have been observed elsewhere, to mark the first great extension of Maiden Castle. The second discovery is that of a third structure on the summit of the hill adjoining the Roman temple and contemporary with it. It is built of dry stone walling, without mortar, and is circular or polyhedral in form. Its character is still under investigation. Further details connected with the east gate have now been made clear. The southern of the two openings, which was previously thought to be an addition, has now been shown, it is reported in The Times of September 26, to be an original feature of the earliest structure, as a causeway of unexcavated chalk runs across the line of the ditch in front of it. This causeway was much mutilated in late Roman times, when the entrance was blocked by a masonry wall built with a core of chalk quarried from the causeway. The line of quarrying, associated with Roman material, has been discovered, and the excavation here is now nearly completed.

\section{Archæological Investigations in the Northern Transvaal}

Remarkable results obtained since 1933 in the excavation of two sites in the Zoutpansberg District, Northern Transvaal, have evoked so many inquiries that Prof. C. van Riet Lowe, director of the Bureau of Archæology, University of South Africa, has been authorized by the Archæological Committee of the University of Pretoria, the body conducting the investigation, to prepare a preliminary report, which appears in Antiquity of September. The two sites, Mapungubwe, and the adjacent and earlier site, Bambandianalo, are situated on a farm near the junction of the Shashi and Limpopo rivers, about one hundred and sixty miles south-west of Zimbabwe, and just over fifty miles due west of Messina, where there are extensive remains of pre-European copper workings. The farm is now the property of the Union Government, having been purchased on the urgent representations of Prof. Leo Fouche. This public-spirited action has proved of inestimable benefit to the advancement of archæological studies in South Africa by making possible the scientific excavation of sites hitherto undisturbed. Notwithstanding the spectacular situation of the Mapungubwe fortress with its dry-stone walling on an inaccessible sandstone cliff, one hundred feet high, and the wealth of gold and other cultural objects found here, in the associated cemetery, and on the earlier site of Bambandianalo (see NATURE, 137, 1024), these sites do not differ essentially from other sites in the region and in Rhodesia, including the Zimbabwe explored by Dr. D. Randall-MacIver and Miss Caton-Thompson; but these latter have suffered from the disturbance of treasure hunters and unauthorized excavation. Hence it has now been possible to establish with certainty a cultural sequence, from which it is inferred that the earlier of the two cultures found here, that of a copper-working pastoral people, may represent the earliest wave of the incursion into what is now South Africa of the Bantu-speaking peoples.

\section{New Aeroplane Height Record}

ON September 28, Squadron Leader F. R. D. Swain, a test pilot at the Royal Aircraft Establish. ment, Farnborough, set up a new height record for 